\title{
Statistical distribution models for migratory fish in Jacuí basin, South Brazil
}

\author{
Thaís P. Alves and Nelson F. Fontoura
}

The aim of the present study was to identify the distribution patterns of migratory fishes in the Jacuí river basin (Rio Grande do Sul, South Brazil), proposing a statistical model of presumed distribution based on geomorphologic environmental data. Through maps of occurrence probability, we hope to contribute to decisions regarding basin environmental management. The analyzed species were: Salminus brasiliensis (dourado), Leporinus obtusidens (piava), Prochilodus lineatus (grumatã) and Pimelodus pintado (pintado). Samples were made through interviews with fishermen and local inhabitants, covering the main channel and tributaries of the rivers Jacuí, Taquari-Antas, Vacacaí, Vacacaí-Mirim, Pardo, Pardinho, Sinos, and Caí. The sampling program resulted in 204 interviews, being 187 considered as valid in 155 different sampling points. The probability of migratory fish occurrence was adjusted through the LOGIT routine of the Idrisi Andes Software: $P=e^{(b 0+b 1 \text {. altitude }+b 2 \text {. basin area })}$. $\left(1+e^{(b 0+b 1} \text {. altitude }+b 2 \text {. basin area) }\right)^{-1}$, where $P$ is the occurrence probability of the species $(0-1)$ and $b_{0}, b_{1}$ and $b_{2}$ are the equation parameters. Model accuracy, for estimating presence, ranged from 82\% to 93\%. Pimelodus pintado was cited to occur in 121 points among the 155 sampled (78.06\%), Prochilodus lineatus in 72 (46.45\%), L. obtusidens in 62 (40.00\%) and S. brasiliensis in 58 (37.42\%). Equation parameters were estimated ( \pm standard error) as follow: S. brasiliensis: $b_{0}=-2.8762 \pm 0.2597 ; b_{1}=-$ $1.3028 \pm 0.0332 ; b_{2}=1.1487 \pm 0.0301 ;$ L. obtusidens: $b_{0}=-0.8364 \pm 0.2213 ; b_{1}=-1.5564 \pm 0.0462 ; b_{2}=0.9947 \pm 0.0206 ;$ Prochilodus lineatus: $b_{0}=0 ; b_{1}=-1.3067 \pm 0.0544 ; b_{2}=0.8128 \pm 0.0177$; Pimelodus pintado: $b_{0}=-0.9487 \pm 0.3688 ; b_{1}=-0.8269 \pm 0.0496 ; b_{2}=$ $0.9255 \pm 0.0304$.

O objetivo do presente estudo foi identificar o padrão de distribuição de peixes migradores da bacia hidrográfica do rio Jacuí (Rio Grande do Sul, Sul do Brasil), propondo um modelo matemático de distribuição presumida baseado em parâmetros ambientais geomorfológicos. Através de mapas de probabilidade de ocorrência, espera-se contribuir para a tomada de decisões relacionadas ao gerenciamento desta bacia hidrográfica. As espécies analisadas foram: Salminus brasiliensis (dourado), Leporinus obtusidens (piava), Prochilodus lineatus (grumatã) e Pimelodus pintado (pintado). As amostras foram obtidas a partir de entrevistas com pescadores e moradores locais, percorrendo-se a calha principal dos rios Jacuí, Taquari-Antas, Vacacaí, Vacacaí-Mirim, Pardo, Pardinho, Sinos e Caí. O programa de amostragens resultou em 204 entrevistas, sendo 187 consideradas como válidas em 155 pontos diferenciados. A probabilidade de ocorrência de peixes migradores foi ajustada

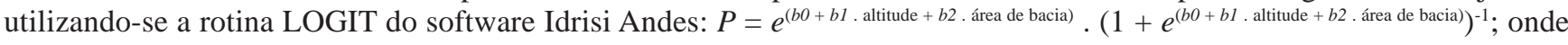
$P$ é a probabilidade de ocorrência da espécie (0-1) e $b_{0}, b_{1}$ e $b_{2}$ são os parâmetros da equação. Pimelodus pintado foi citado como presente em 121 pontos dentre os 155 amostrados (78.06\%), Prochilodus lineatus em 72 (46.45\%), L. obtusidens em 62 (40.00\%), e S. brasiliensis em 58 pontos (37.42\%). A precisão do modelo, para a presença estimada, ficou entre $82 \%$ e 93\%. Os parâmetros estimados da equação são descritos a seguir: $S$. brasiliensis: $b_{0}=-2.8762 \pm 0.2597 ; b_{1}=-1.3028 \pm 0.0332 ; b_{2}=1.1487$ $\pm 0.0301 ;$ L obtusidens: $b_{0}=-0.8364 \pm 0.2213 ; b_{1}=-1.5564 \pm 0.0462 ; b_{2}=0.9947 \pm 0.0206 ;$ Prochilodus lineatus: $b_{0}=0 ; b_{1}=-1.3067$ $\pm 0.0544 ; b_{2}=0.8128 \pm 0.0177 ;$ Pimelodus pintado: $b_{0}=-0.9487 \pm 0.3688 ; b_{1}=-0.8269 \pm 0.0496 ; b_{2}=0.9255 \pm 0.0304$.

Key words: Salminus brasiliensis, Leporinus obtusidens, Prochilodus lineatus, Pimelodus pintado, Generalized Linear Models.

\section{Introduction}

More than $15 \%$ of the Neotropical fish fauna is composed by migratory species (Carolsfeld et al., 2004), which may need to cover several kilometers to stimulate gonadal maturation (Godoy, 1987). The watershed area for maintaining most of these species could reach $40.000 \mathrm{~km}^{2}$ (Godoy, 1987). Spawning use to happen upstream the adult feeding areas, and stream current carries the eggs and larvae to areas where they will develop. In these sites, juveniles will feed and grow until they become big enough to join the main stock (Pitcher \& Hart, 1982).

Malabarba (1989) presents a list of species of freshwater fish of Patos Lagoon drainage, which includes the Jacuí River. Following Agostinho \& Júlio (1999) and Vazzoler et al. (1997), the migratory species for Jacuí basin are: Salminus brasiliensis

Faculdade de Biociências, Pontifícia Universidade Católica do Rio Grande do Sul (PUCRS). Av. Ipiranga, 6681, Caixa Postal 1429, 90619900 Porto Alegre, RS, Brazil. alves.thais@uol.com.br (TPA),nfontoura@pucrs.br (NFF) 
(Cuvier, 1816) (dourado); Prochilodus lineatus (Valenciennes, 1836) (grumatã); Leporinus obtusidens (Valenciennes, 1836) (piava); and Pimelodus pintado Azpelicueta, Lundberg \& Loureiro, 2008 (pintado). The spotted catfish of the Patos basin was known until recently as Pimelodus maculatus Lacépede, 1803, a species with wide distribution in neotropics and maybe a species complex. After Azpelicueta, Lundberg \& Loureiro (2008) the Patos spotted catfish was reviewed and described as Pimelodus pintado, with few information concerning migratory or reproductive biology but maybe with similar biological patterns as Pimelodus maculatus.

Nevertheless, including Pimelodus pintado as a migratory fish species is still controversial. Braun (2005) suggests that the species seems to reproduce in little channels, tributaries of Patos Lagoon. This information is reinforced by the occurrence of Pimelodus pintado in Barros lagoon, which receives water from only small creeks of first order, suggesting no dependence of large scale migration for reproductive purpose. However, considering the importance of this species for artisanal fishery, Pimelodus pintado will be included among the compulsory migrant species of the Jacuí River basin.

A river is a complex system, with continuous changing structure from upstream to lower areas. The species richness increases downwards (Reyes-Gavilán et al., 1996) and in higher altitudes both physical and chemical conditions are more stressful, with a lower number of species showing physiological and ecological capacities to survive in such places (Matthews \& Styron-Júnior, 1981).

As a general rule, the distributional limit of a species is driven by several factors, which combine or interact to create the patterns found in nature (Hall et al., 1992). The altitude, for example, seems to be broadly related to hydrodynamics and morphology of a river. With the combined factors such as water temperature, conductivity, $\mathrm{pH}$, current speed, declivity, and the presence of pools and waterfalls, altitude is capable of creating an environmental gradient that exerts influence on the species richness in each region (Pouilly et al., 2006). Araújo \& Tejerina-Garro (2009), found that $\mathrm{pH}$, water velocity, channel width and water temperature strongly affected fish assemblages in upper Paraná tributaries. Using geomorphologic data, Súarez \& Petrere-Júnior (2007) suggested altitude as the most important structuring factor to fish community in the Iguatemi River basin. Apart from altitude, the water volume drained to a specific point seems to exert a large influence on the fish distribution patterns (Garutti, 1988). When the altitude decreases, there is an increase in the width and deep of the river, allowing the survival of bigger fish species (Vázquez et al., 1979).

Brazil has approximately 4360 dams, not taking into account homemade barriers and/or non-registered ones (Silveira \& Cruz, 2005). Currently, 90\% of the Brazilian electric power production is generated by hydroelectric turbines (PetrereJúnior et al., 2002). Hydroelectric plants have been interfering in fish migration all around the world. Knowing the longitudinal distribution of migratory fishes is an important tool to support decisions related to dams planning in a regional scale. In this respect, predicting species occurrence through a modeling approach based on geographical information system (GIS) represents a useful methodological tool (Pearce \& Ferrier, 2000b).

Generalized linear models (GLM), implemented within a GIS are especially useful as it can be applied with many types of predictors (continuous, binary, qualitative, and ordinal), and the distribution of the species should comprise just presence and absence data (Syartinilia \& Tsuyuki, 2008), information available through interviews. These models are then applied to extrapolate the probability of occurrence of species across the entire region of interest (Pearce \& Ferrier, 2000b).

Although several ecological factors are known to influence fish distribution patterns, access to such data is not easy or even accurate at large areas. In a large regional scale, the use of simple factors derived from GIS, as altitude and basin area, seems to be enough for understanding distributional patterns along the rivers (Matthews et al., 1992; Pouilly et al., 2006).

The present study aims to identify the longitudinal historical distribution pattern of long distance migratory fish in the hydrographic basin of the Jacuí River, which already has an installed hydroelectric production of 1.428,674 MW, and a potential, still not installed one, of 271,004 MW. Apart from presenting distribution maps for long distance migratory fish, probabilistic distribution models for each species will also be proposed, using altitude and basin area as main presence predictors.

\section{Material and Methods}

Eight field expeditions were carried out, covering the most important rivers draining to the Jacuí basin: Taquari-Antas, Vacacaí/Vacacaí-Mirim, Pardo/Pardinho, Sinos and Caí, as their main tributaries. The samplings were performed between February and July of 2007. Expeditions were carried out making use of the road network and its crossing points with the rivers, resulting in 155 different sampling points (Fig. 1).

At each sampling site, local fishermen and oldest residents were searched and interviewed. With the aid of a board containing a picture of interest species, each interviewed person was asked about their knowledge of the fishes, and then, their presence or absence in that specific river segment (present or historical). In case of more than one interview at the same sampling site, only the most frequent information or consensus was registered. The project totalized 204 interviews, 187 registered as useful in 155 different points.

Also, a survey in the main Brazilian fish collections was done by using the SIBIP/NEODAT III database (MCP, MNRJ, MZUSP, UFRGS); besides literature information (Petry \& Schulz, 2006). This survey was extended through the analysis of Environmental Impact Reports (EIA-RIMA) produced for the licensing power-dams (UHE) in the Jacuí and TaquariAntas basins (Dona Francisca; 14 de Julho, Castro Alves, Monte Claro).

Data analysis and cartographic products were performed 
using Idrisi Andes software (Clarck Labs, 2006) and a digital elevation model (DEM, radar altitude in pixel of 92.6 per 92.6 $\mathrm{m}$ ) for the Brazilian official reference system (SAD 69; Labgeo, 2006).

The hydrographic matrix was obtained through four basic steps: (1) DEM homogenization by applying the Filter Min $3 x 3$ pixels; (2) defining pathways with monotonically decreasing attitudes through Pit Removal tool; (3) by applying the Runoff tool to estimate the upstream catchment area for each pixel, correcting pixel number for the real area $\left(\mathrm{km}^{2}\right)$ by multiplying pixel values by 0.00857476 ; (4) converting each pixel with catchment area smaller then 10 to zero and bigger then 10 into one, and then creating a hydrographic matrix with watershed bigger then $10 \mathrm{~km}^{2}$. Hydrographic matrix with fish presence, for each species, was created through Pathway tool, using recorded presence (GPS coordinates) as Target Image and the DEM as Cost Surface. Mask for data analysis was obtained by using also the Pathway tool, with upstream sampled coordinates as Target Image and the DEM as Cost Surface.

The occurrence probability for each migratory fish species throughout the hydrographic matrix was estimated using the
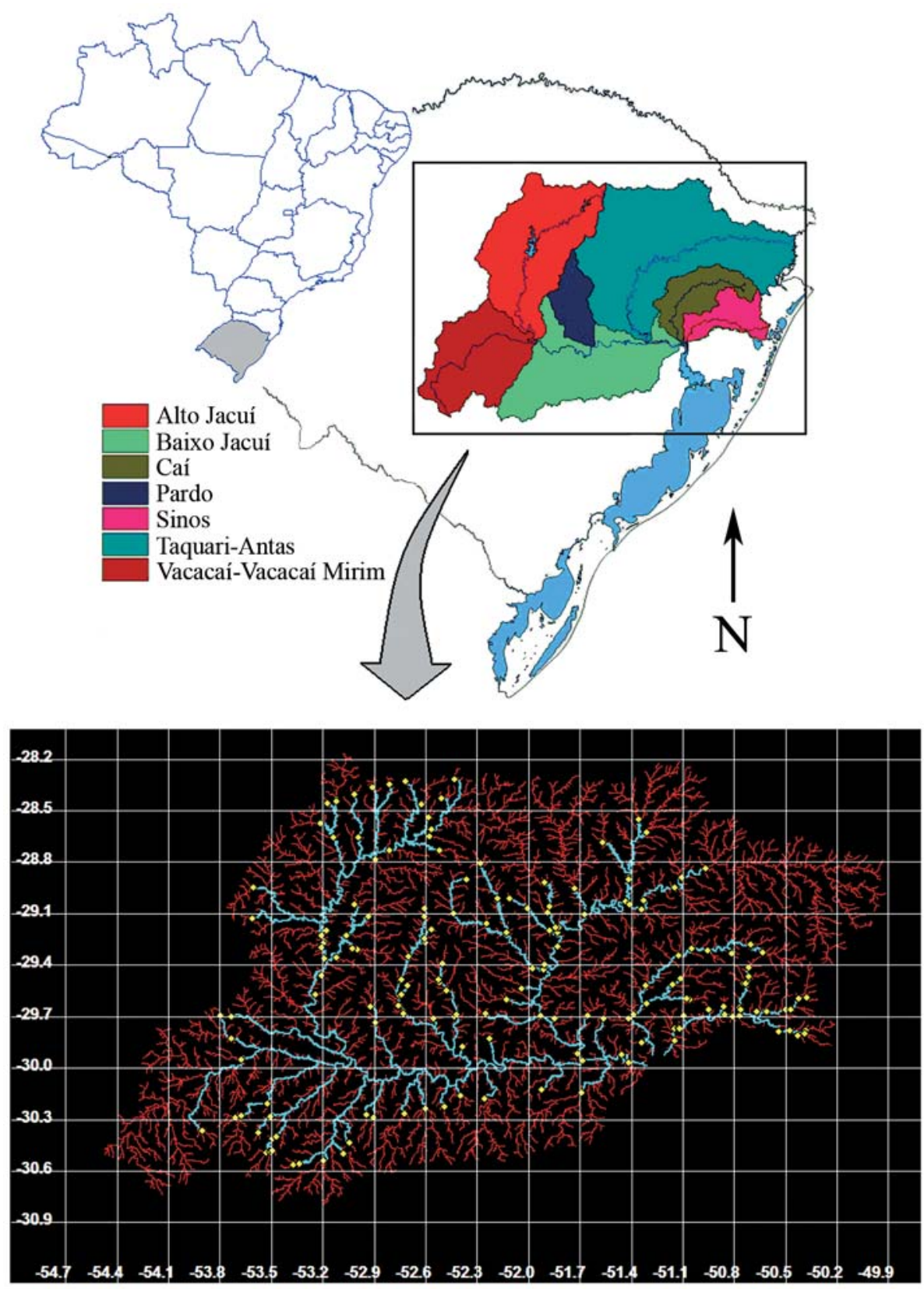

Fig. 1. Sampling sites $(n=155)$ covering the main channel and tributaries of the rivers Jacuí, Taquari-Antas, Vacacaí, VacacaíMirim, Pardo, Pardinho, Sinos and Caí. Hydrographic map generated through a digital elevation model (DEM, radar altitude in pixel of 92.6 per $92.6 \mathrm{~m}$ ) for the Brazilian official reference system (SAD 69; Labgeo, 2006). 
Multinomial Logistic Regression routine (Logisticreg, adjust by maximum likelihood through the Newton-Raphson algorithm): $P(\mathrm{X}=1)=e^{(b 0+b 1 \text {. altitude }+b 2 \text {. basin area })} \cdot\left(1+e^{(b 0+b 1 \text {. altitude }}\right.$ $+b 2$. basin area) $)^{-1}$, where $P(\mathrm{X}=1)$ is the occurrence probability of the species and $b_{0}, b_{1}$ and $b_{2}$ are the equation parameters. The measured variables, the measurement scale and data source is described in Table 1.

Data analysis was performed in two steps. First, the probability model for each species was estimated using data from 175 interviews from 150 different points, including literature, EIA-RIMA and museum data. A residual map was generated showing differences among observed presence $(0 / 1)$ and predicted presence probability. Sampling points with residuals larger then 0.5 were revisited for new interviews. During this new field trip, additional 29 interviews and five new points were introduced into de original data matrix for new model processing. Adherence between informed distribution and presumed distribution were estimated as the percentage of the river segments with presence/absence informed as correct, according to the presumed distribution model (considered as presumed presence probabilities higher than 0.5 and as presumed absence probabilities lower than 0.5 ).

Considering that the Logisticreg function of the Idrisi Andes software does not estimate the standard errors of the adjusted parameters, 10 independent adjustments were carried out for each species through random selection of $10 \%$ of the pixels from de sample matrix. The standard errors were calculated as the standard deviation of the different estimates for each parameter, obtaining the significance thorough the Wald statistic, the ratio between the estimated parameter and its standard deviation, calculating $\mathrm{P}$ through the $\mathrm{Z}$ distribution (Tabachnick \& Fidell, 1996).

Table 1. Measured variables, measurement scale and data source for probability distribution models adjustment for migratory fishes at Jacuí basin (Brazil).

\begin{tabular}{lll}
\hline \multicolumn{1}{c}{ Variable } & \multicolumn{1}{c}{ Measurement Scale } & \multicolumn{1}{c}{ Data Origin } \\
\hline $\begin{array}{l}\text { Presence (per specie } \\
\text { of migratory fish) }\end{array}$ & $\begin{array}{l}\text { Binary: } \\
\text { present (1); absent (0) }\end{array}$ & $\begin{array}{l}\text { Presence in catalogues } \\
\text { Records in literature } \\
\text { Interviews }\end{array}$ \\
Altitude & $\begin{array}{l}\text { Metric (natural logarithm } \\
\text { of the altitude in meters) }\end{array}$ & Digital Elevation Model \\
Catchment area & $\begin{array}{l}\text { Metric (natural logarithm } \\
\text { of the basin area in } \mathrm{km}^{2} \text { ) }\end{array}$ & Digital Elevation Model \\
\hline
\end{tabular}

\section{Results}

Search in available information (museums, literature, EIARIMA) resulted in just five occurrences for $S$. brasiliensis, 13 for Prochilodus lineatus, 16 for L. obtusidens and 26 for Pimelodus pintado. Pimelodus pintado was present in 121 points among the 155 sampled (78.06\%), Prochilodus lineatus in 72 (46.45\%), L. obtusidens in 62 (40.00\%) and S. brasiliensis in $58(37.42 \%)$.

Is shown in Fig. 2 the cumulative frequency of informed occurrence as a function of altitude and catchment area. Results were similar for all the species but Pimelodus pintado. As identified, Prochilodus lineatus, L. obtusidens and $S$. brasiliensis have an altitudinal threshold of about 280-300 m whereas Pimelodus pintado was recorded in altitudes exceeding $500 \mathrm{~m}$ (one informed occurrence at $680 \mathrm{~m}$ ). Occurrences, concerning basin area, were recorded for all species in river segments with catchments over $20 \mathrm{~km}^{2}$.

The estimated parameters for the probability model for each species are shown in Table 2. Table 3 presents the adherence between informed distribution and presumed distribution.

For each analyzed species, Figs. 3 to 6 show (a) hydrographic map of the informed occurrence through the interviews, as well as the registered occurrence points in literature and museums; (b) probability map of the presumed occurrence through the adjusted logistic model to the whole hydrographic basin with a catchment area larger than $10 \mathrm{~km}^{2}$;
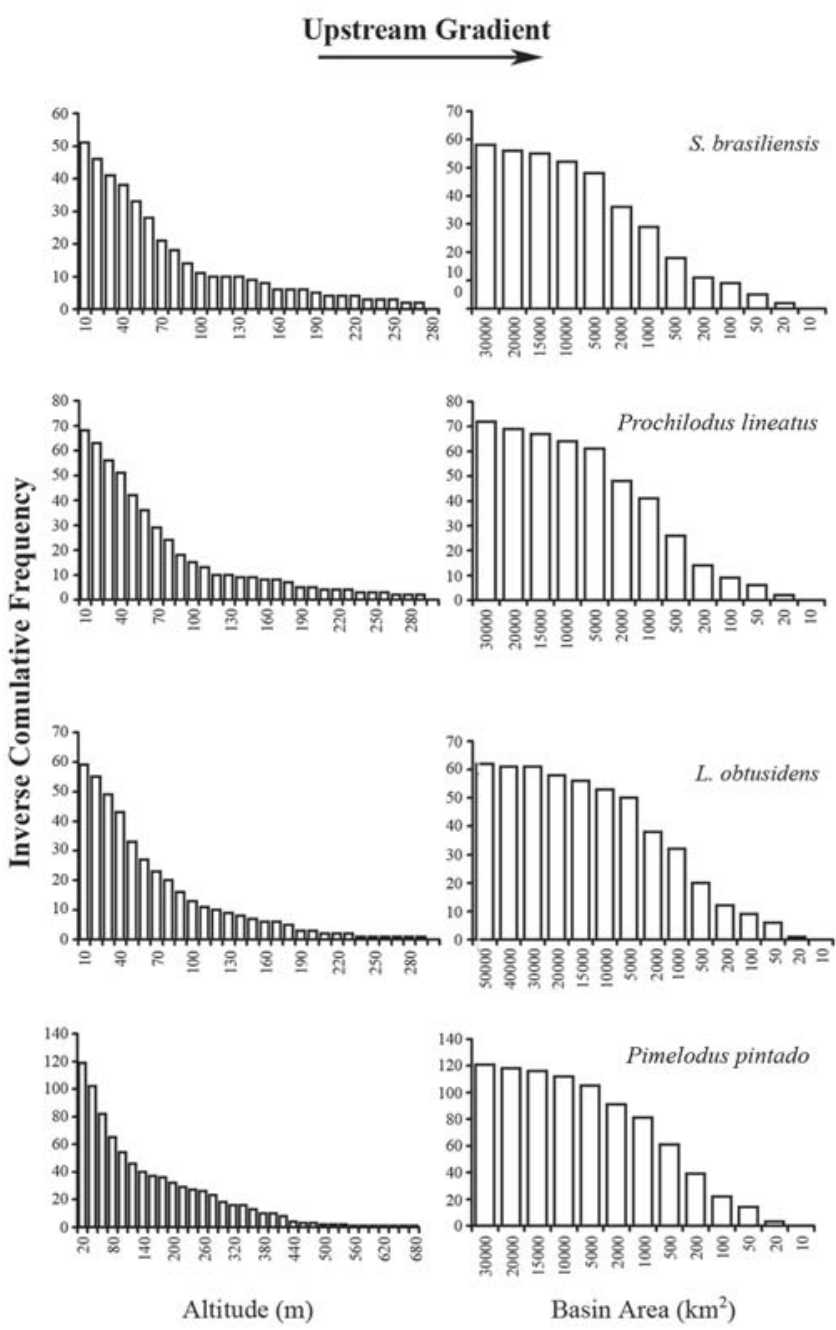

Fig. 2. Inverse cumulative frequency of informed occurrence of migratory fish of Jacuí basin according to an upstream gradient of altitude $(\mathrm{m})$ and basin catchment $\left(\mathrm{km}^{2}\right)$. 
Table 2. Average, Standard Deviation, Wald and significance of the coefficients (Intercept, $b_{0}$; altitude, $b_{1}$; and basin area, $b_{2}$ ) estimated from ten independent adjustments of the logistic regression performed using the software Idrisi Andes to each of the four migratory fish species in Jacuí basin (Brazil). S.D. $=$ Standard Deviation.

\begin{tabular}{llccc}
\hline \multirow{2}{*}{ Species } & & \multicolumn{3}{c}{ Regression Coeficients } \\
\cline { 3 - 5 } S. brasiliensis & & Intercept & Altitude $(\mathrm{m})$ & Basin Area $\left(\mathrm{km}^{2}\right)$ \\
\hline \multirow{5}{*}{ Prochilodus lineatus } & Average & -2.8762 & -1.3028 & 1.1487 \\
& S.D. & 0.2597 & 0.0332 & 0.0301 \\
& Wald & 11.0735 & 39.2022 & 38.1045 \\
& p & $<0.0001$ & $<0.0001$ & $<0.0001$ \\
& Average & -0.3176 & -1.3067 & 0.8128 \\
& Wald & 0.2731 & 0.0544 & 0.0177 \\
& p & 0.1628 & 23.9999 & 45.9075 \\
L. obtusidens & Average & -0.8364 & -1.5564 & 0.9947 \\
& S.D. & 0.2213 & 0.0462 & 0.0206 \\
& Wald & 3.7789 & 33.6909 & 48.1894 \\
& p & 0.0036 & $<0.0001$ & $<0.0001$ \\
& Average & -0.9487 & -0.8269 & 0.9255 \\
Pimelodus pintado & S.D. & 0.3688 & 0.0496 & 0.0304 \\
& Wald & 2.5722 & 16.6855 & 30.4644 \\
& p & 0.0278 & $<0.0001$ & $<0.0001$ \\
\hline
\end{tabular}

Table 3. Mean accuracy percentage (adherence) of the presumed occurrence model for each one of the four migratory fish species in Jacuí basin (Brazil).

\begin{tabular}{lcccc}
\hline & S. brasiliensis & P. lineatus & L. obtusidens & P. pintado \\
\hline Presence adherence (\%) & 83.2 & 82.0 & 82.9 & 93.3 \\
Absence adherence (\%) & 84.2 & 81.3 & 85.0 & 48.9 \\
\hline
\end{tabular}

and (c) distribution map of residuals, highlighting points in which the difference between informed occurrence and estimated probability was higher than 0.3 (33\%).

Considering the effects of dams as barriers to fish migratory movements, Fig. 7 presents the cumulative distribution of large and small power dams of the Jacuí basin ( $n=24$, data from National Electric Power Agency - ANEL) according to an altitudinal gradient. As could be identified, around $50 \%$ of registered dams are present above the altitudinal threshold of 280-300 m. Figure 8 presents the geographical distribution of power dams (yellow spots) in the Jacuí basin according to altitudinal categories of under $300 \mathrm{~m}$ (red river segments) and over $300 \mathrm{~m}$ (green river segments). Inspecting the spatial distribution, it becomes clear that most of the constructed power dams are located above or near the altitudinal threshold of 280-300 m of upper migratory fish distribution, suggesting that most operating power dams presents little effect as barriers for upstream movements for migratory fish.

\section{Discussion}

In the last twenty years, the use of multivariate statistic in the modeling of species distribution has increased through the application of a large variety of techniques. Particularly, the regression models have been broadly used to predict distribution, abundance and habitat preference of species (Brito et al., 1999). However, when this information is joined with Geographic Information Systems (GIS), it is possible to incorporate ecological factors directly obtained from remote images to prediction models. Also, indirect gradients constituted by variables that do not show direct physiological action, as altitude, declivity and topographic position, are easier to be obtained than environmental parameters of direct gradient, such temperature or $\mathrm{pH}$, which often introduce spatial uncertainties due to the lack of data and interpolation bias (Guisan et al., 1999).

Although in the present work we have opted to model distribution based just in two parameters of indirect gradient, altitude and catchment area, the predicted distribution, when confronted with the informed distribution, always produced an adherence ratio higher than $80 \%$. The combined effect of both variables suggest that altitude is the main factor limiting migratory fish distribution for areas comprising the Serra Geral (altitudinal areas) whereas catchment area limits distribution in the plains of the Central Depression of Rio Grande do Sul. This result suggests that even a relatively small set of geomorphologic variables are able to show an important predictive power, maybe due to colinearity effects with associated direct parameter, such as water temperature, river dimension (deep, width), current speed and turbidity.

Nevertheless, even considering adherence over than 80\% as satisfactory, the resulted error should not be neglected. Among the factors contributing to the observed residues are: (1) information mismatch; (2) deficiency in determining the exact point of species disappearance into a river system; (3) influence of other environmental factors, such as barrier downstream; and (4) the intrinsic variability related to any natural phenomena.

Although we have tried to minimize the probability of mistaken information, through a resample process of discrepant interviews (validation), this process was limited to river segments in which residuals (both positive and negative) were higher than 0.5 for at least two species, due to the large geographical area under analysis. Also, new interviews resulted mostly into confirmation of previous data and no significant change was obtained.

On the other hand, the methodological approach used in this work, statistic operation of images instead of direct numeric data, presents advantages and disadvantages that need closer examination. The main advantage consists in increasing the available data set. Pearce \& Ferrier (2000b) identified a sharp increase in predictive performance of GLM as sample size is increased from 50 to 250 sites. By applying conventional statistic software, each point is an independent sample, with measured attributes. In the present work, we have 155 different points spread in the Jacuí basin. However, by using Geographic Information System (GIS) and statistic operation of images, additional information could be incorporated. When the presence of a species is registered in adjacent points of a river, it is reasonable to suppose that the species do also occurs along the whole segment between these two points. 

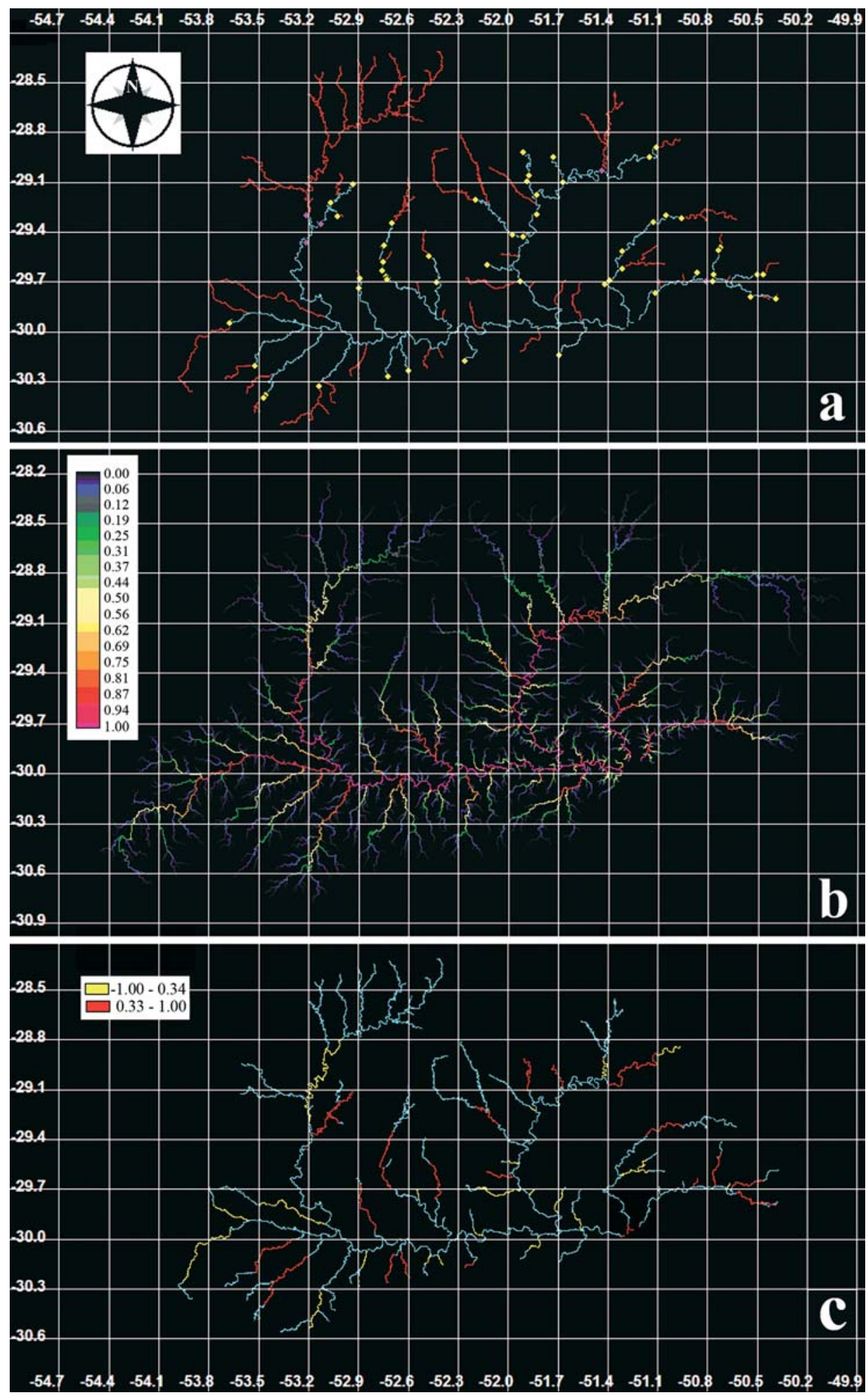

Fig. 3. Salminus brasiliensis. (a) Hydrographic map of presumed occurrence (blue) through interviews (yellow spots), literature and museums (purple spots) over sampled hydrography (red). (b) Probability map of the presumed occurrence through the adjusted logistic model to the whole hydrographic basin with a catchment area higher than $10 \mathrm{~km}^{2}$. (c) Distribution map of residuals applied to sampled hydrographic basin. Red segments represent negative residuals less then -0.34, indicating predicted presence but with no registered occurrence. Yellow segments represent positive residuals greater then 0.34, indicating registered occurrence do not predicted by the model. Hydrographic maps generated through a digital elevation model (DEM, radar altitude in pixel of 92.6 per $92.6 \mathrm{~m}$ ) for the Brazilian official reference system (SAD 69; Labgeo, 2006). 

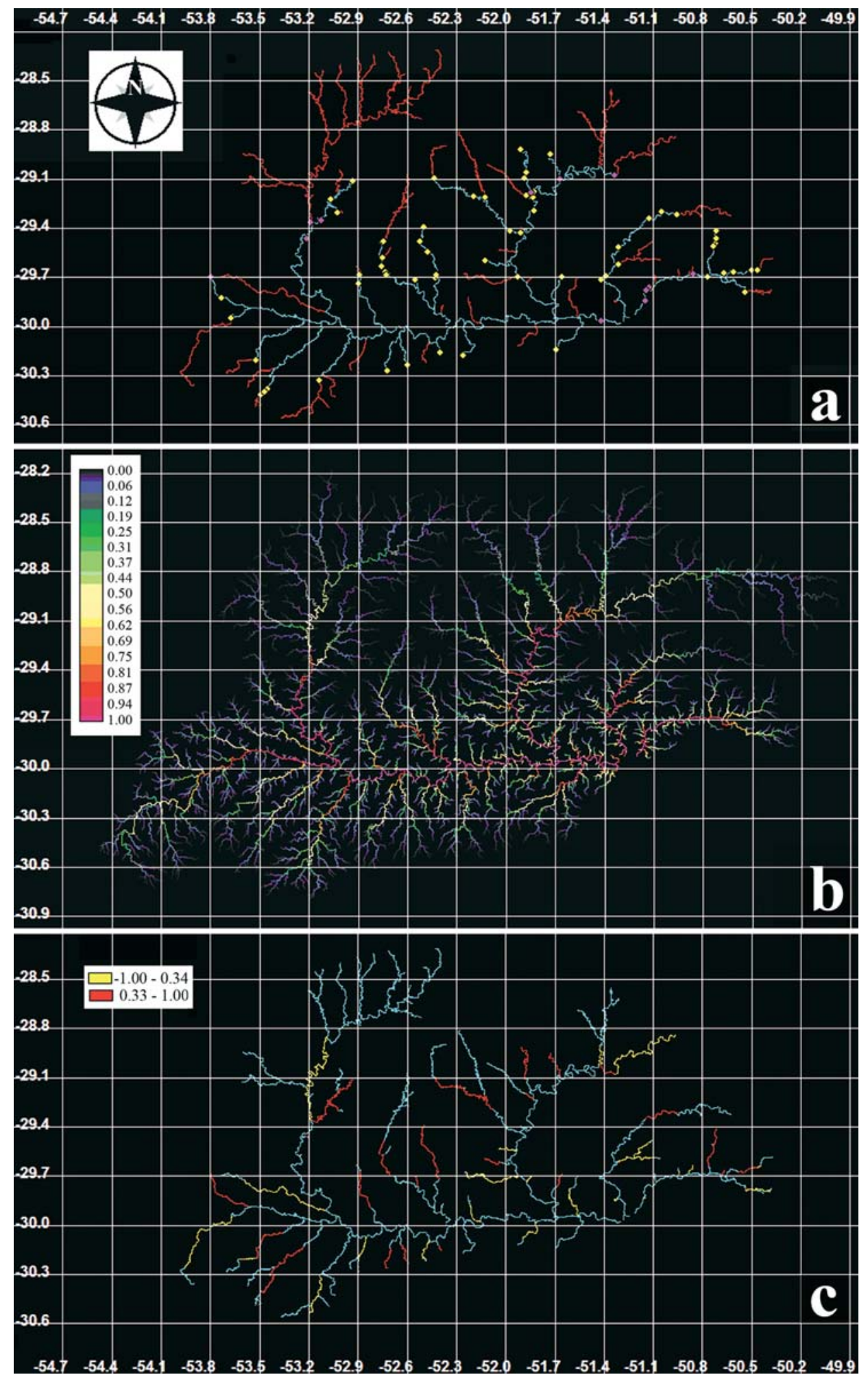

Fig. 4. Prochilodus lineatus. (a) Hydrographic map of presumed occurrence (blue) through interviews (yellow spots), literature and museums (purple spots) over sampled hydrography (red). (b) Probability map of the presumed occurrence through the adjusted logistic model to the whole hydrographic basin with a catchment area higher than $10 \mathrm{~km}^{2}$. (c) Distribution map of residuals applied to sampled hydrographic basin. Red segments represent negative residuals less then -0.34 , indicating predicted presence but with no registered occurrence. Yellow segments represent positive residuals greater then 0.34 , indicating registered occurrence do not predicted by the model. Hydrographic maps generated through a digital elevation model (DEM, radar altitude in pixel of 92.6 per $92.6 \mathrm{~m}$ ) for the Brazilian official reference system (SAD 69; Labgeo, 2006). 

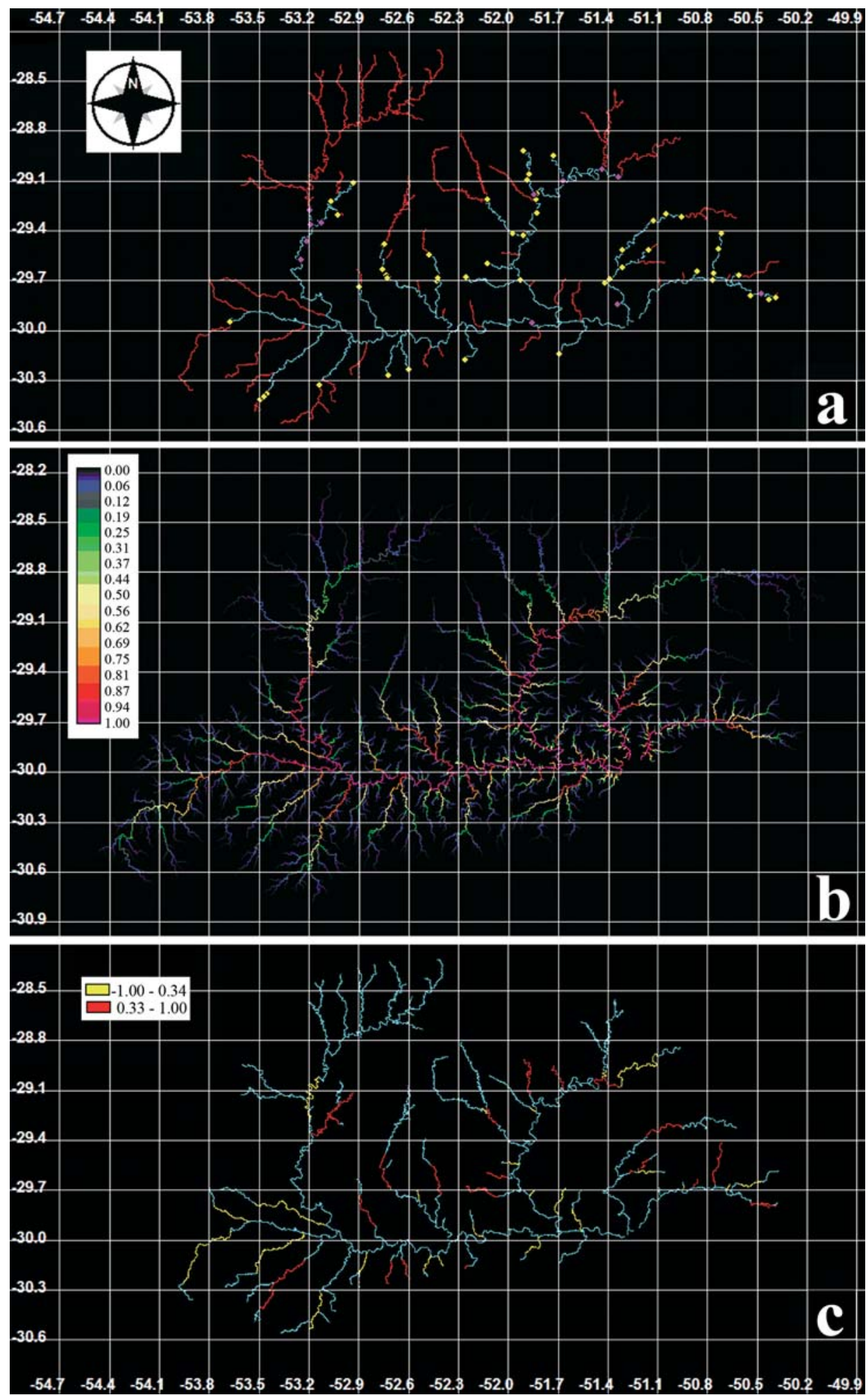

Fig. 5. Leporinus obtusidens. (a) Hydrographic map of presumed occurrence (blue) through interviews (yellow spots), literature and museums (purple spots) over sampled hydrography (red). (b) Probability map of the presumed occurrence through the adjusted logistic model to the whole hydrographic basin with a catchment area higher than $10 \mathrm{~km}^{2}$. (c) Distribution map of residuals applied to sampled hydrographic basin. Red segments represent negative residuals less then -0.34, indicating predicted presence but with no registered occurrence. Yellow segments represent positive residuals greater then 0.34, indicating registered occurrence do not predicted by the model. Hydrographic maps generated through a digital elevation model (DEM, radar altitude in pixel of 92.6 per 92.6 m) for the Brazilian official reference system (SAD 69; Labgeo, 2006). 

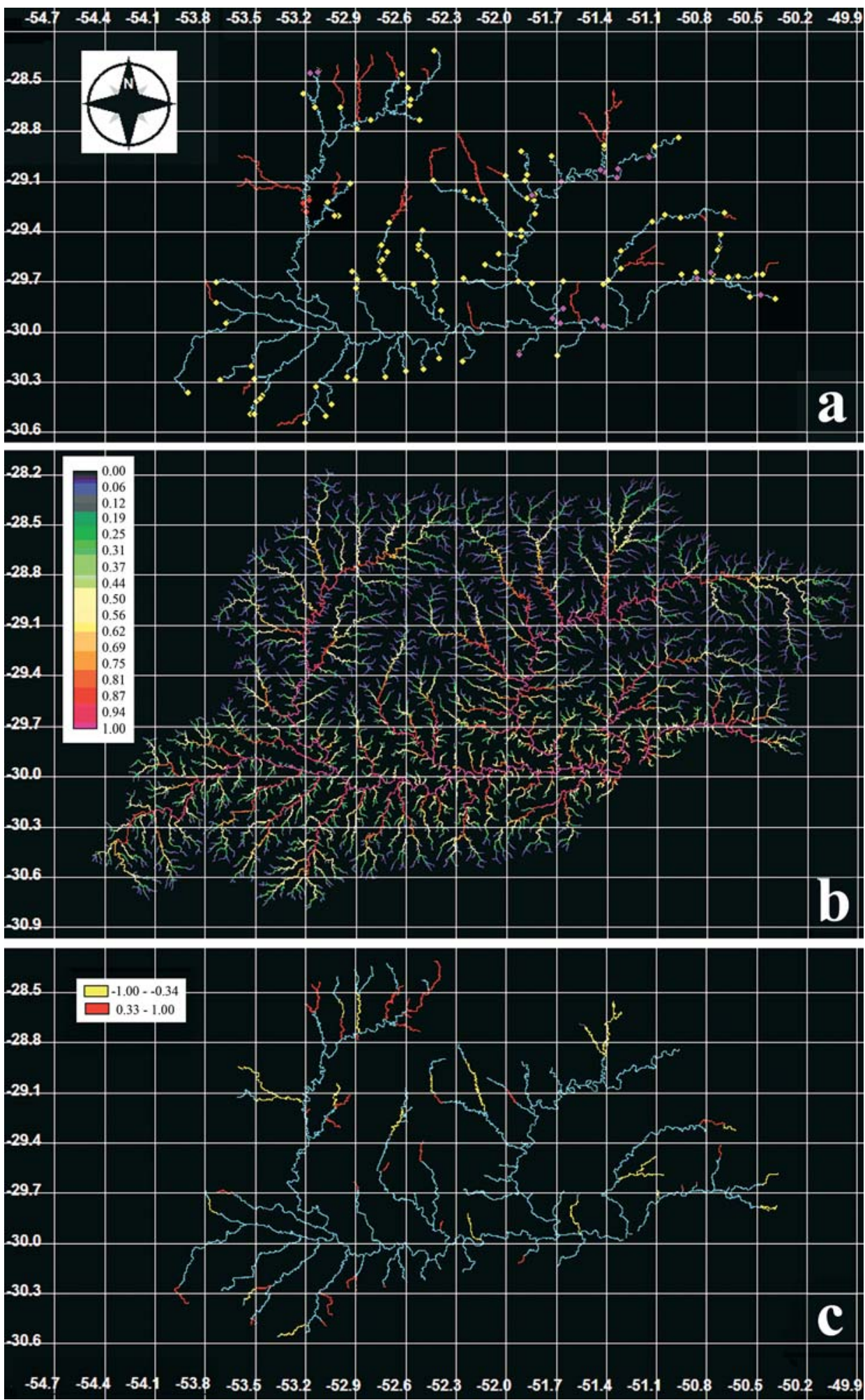

Fig. 6. Pimelodus pintado. (a) Hydrographic map of presumed occurrence (blue) through interviews (yellow spots), literature and museums (purple spots) over sampled hydrography (red). (b) Probability map of the presumed occurrence through the adjusted logistic model to the whole hydrographic basin with a catchment area higher than $10 \mathrm{~km}^{2}$. (c) Distribution map of residuals applied to sampled hydrographic basin. Red segments represent negative residuals less then -0.34 , indicating predicted presence but with no registered occurrence. Yellow segments represent positive residuals greater then 0.34 , indicating registered occurrence do not predicted by the model. Hydrographic maps generated through a digital elevation model (DEM, radar altitude in pixel of 92.6 per $92.6 \mathrm{~m}$ ) for the Brazilian official reference system (SAD 69; Labgeo, 2006). 


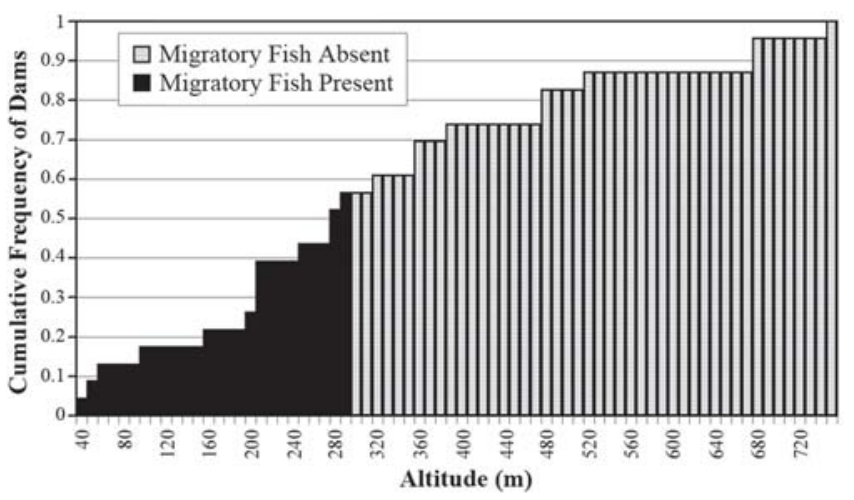

Fig. 7. Cumulative frequency of dam distribution in Jacuí basin according to altitude $(\mathrm{m})(\mathrm{n}=24)$.

By using image operation, this information can be retrieved, increasing the sampling effort. In the other hand, when a species is not registered in a sampling point, is reasonable to consider that it will be absent from that point to upstream.

With the aid of this procedure, a matrix of around 40 thousand information points (pixels) was created, with presence/absence data for each species, as well as the information of altitude and catchment area. This protocol allowed us to perform independent adjustments for each species, using in each only $10 \%$ of the sampled points (approximately four thousand points), in a bootstrap process to estimate the confidence intervals for the adjusted coefficients.

The process, however, could incorporate bias at an inverse proportion to the density of the sample matrix. When a species disappears between two sampling points, this analysis protocol considers it as absent from the last point with informed presence. If the points are distant apart, a considerable segment of probable presence will be computed as absence. The bigger the density of sampled points in the distribution limits, the smaller the errors from the analysis process. This kind of possible bias was the reason driving our priority for sampling in the upstream segments of main rivers instead of the lower areas.

The error margin could even have suffered the influence of other factors not included in the model, as the presence of downstream barriers. Moreover, the incorporation of natural barriers into the present model was presently unviable. Although a lot of natural barriers have been identified in loco, the DEM precision by using pixel of 92 per 92 meters and altitude information coming from a radar sensor, appeared to be inadequate for the identification of potentially significant small accidents, so that we opted to not include this variable in the proposed model. Also, to include information related to dam presence brings other problems as dam age and the presence and effectiveness of transposition facilities. So, the final distributional models of the present work intend to identify the historical distribution of migratory fish along the Jacuí basin, do not including the subsequent interference of constructed dams or barriers. This historical distribution, however, could be biased (underestimated) if interviewed residents were younger than operating power dams. Large power-dams in the basin are operating since 1952 in the Caí River (UHE Bugres, 544 m altitude), 1962 in the upper Jacuí (UHE Jacuí, $270 \mathrm{~m}$ altitude) and 2004 in the Taquari-Antas (UHE Monte Claro, $150 \mathrm{~m}$ altitude) allowing to identify undisturbed fish presence from old residents for most of the basin. Although a lot of small units are much older and widespread, they are located mainly in small tributaries and upper altitudes, with small probability of fish occurrence.

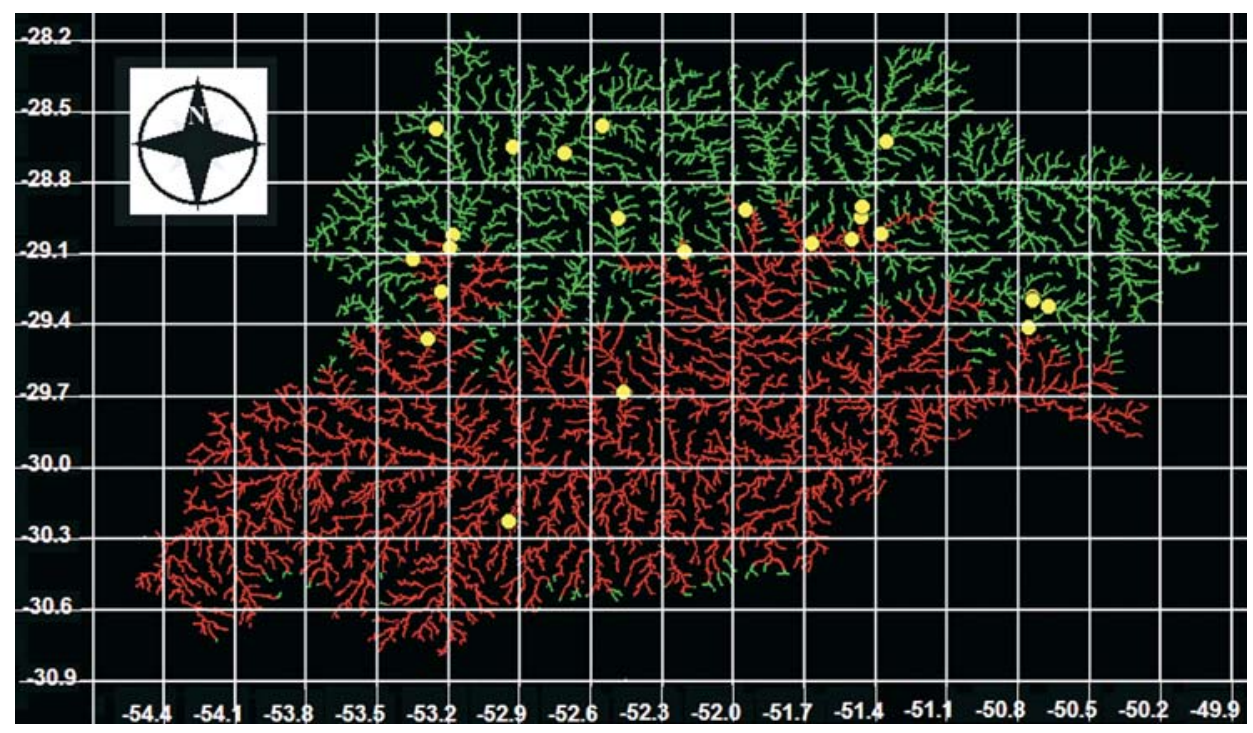

Fig. 8. Hydrographic map of the Jacuí basin with dam distribution (yellow spots). Red river segments are below the altitudinal threshold of $300 \mathrm{~m}$ (green above this limit). Hydrographic maps generated through a digital elevation model (DEM, radar altitude in pixel of 92.6 per 92.6 m) for the Brazilian official reference system (SAD 69; Labgeo, 2006). 
By interpreting each species distribution pattern, it is interesting to identify that Pimelodus pintado presents a relative low accuracy in relation to estimated absence (48\%). This low adherence can be related to two factors: (1) possible intentional introduction of the species in upstream areas, or (2) the natural transposition of barriers through dam flooding. The introduction of the Pimelodus pintado was informed by residents in the surroundings of the Salto System. According to them, individuals of Pimelodus pintado were introduced in the flooded area of the Divisa Dam (Caí River). Also residents of the upper Jacuí reported that the species started to be captured only after the construction of Maia Filho and Passo Real Dams, suggesting possible transposition of natural barriers due to lake flooding.

By observing the species presumed distribution maps, it is possible to verify that a considerable superposition has occurred. The altitude coefficients obtained for the four species showed a negative influence of this parameter over the analyzed species distribution. With higher altitudes the smaller habitat heterogeneity and the dynamic instability determine conditions in which few species are able to tolerate (Bistoni \& Hued, 2002). In rivers of central Argentina, distribution of the species according to an altitudinal gradient was also observed: Pimelodus albicans reaches altitudes between 600 and $800 \mathrm{~m}$; Prochilodus platensis (= P. lineatus), between 400 and $600 \mathrm{~m}$; and Salminus maxillosus (=S. brasiliensis), between 200 and 400 m (Bistoni \& Hued, 2002). In the present study, we observed that Pimelodus pintado (680 m) and Prochilodus lineatus (297 m) occurred in lower altitudes than their co-generic species from Argentina, although S. brasiliensis ( $292 \mathrm{~m}$ ) presented the same altitudinal pattern of S. maxillosus (= S. brasiliensis). Even so, in both cases the genus maintained the same altitudinal sequence, with Pimelodus reaching upstream areas, suggesting the existence of a phylogenetic component in the habitat distribution pattern.

The upstream catchment area appears to be extremely significant to explain the distribution pattern of the four species, with positive coefficients, showing the preference of the species for downstream segments. When reported for small upstream segments, migratory fish presence was frequently associated with unusual floods and not as a regular occurrence. However, direct comparisons among the occurrence probabilities of the species should not be done taking into account each coefficient independently. The nature of the multiple regression models, due to the variables multicolinearity, may result in difficulties to correctly identify the individual effects of each coefficient (Hise et al., 1983). However, S. brasiliensis and Prochilodus lineatus, which presented almost the same altitude coefficients, can be directly compared in relation to the catchment area coefficient. Despite suffering similar influence from the altitude over their distribution, the $S$. brasiliensis seems to be more affected by water volume, requiring larger river dimension to fix its occurrence.

Available information suggest that $S$. brasiliensis and Prochilodus lineatus need at least $100 \mathrm{~km}$ of unobstructed river segments to complete gonad development and the spawning process (Agostinho et al., 2004). There is no information concerning Pimelodus pintado, although Pimelodus maculatus needs shorter segments to spawn (Godoy, 1967), apparently being a species which is less affected by artificial barriers.

Concerning the usefulness of distribution predictability, Generalized Linear Models (GLM) could be interpreted by two distinct ways (Pearce \& Ferrier, 2000a). Reliable predictions may be used as if each predicted probability can be an accurate estimate of the likelihood of detecting the species at a given area. For example, an estimated 0.8 probability means that the species has a real likelihood of presence of $80 \%$. On the other hand, a model with good discrimination ability is the one that can only discriminate between occupied $(p>0.5)$ and unoccupied sites $(p<0.5)$, but estimated probabilities may be not accurate (Pearce \& Ferrier, 2000a).

The proposed models (standard GLM), imply that the effect of each environmental variable is linear (multiplied by a constant), that is, an increase of the value of the variable from, for example, 100 to 200 has the same effect than an increase from 500 to 600 , despite the sigmoid pattern of the probability distribution. Nevertheless, the effect of an environmental variable may follow a more complex pattern, emulating a linear effect only on a specific range of values. Some species, for example, may occur in the middle segment of large rivers, and may be rare upstream or downstream. For this kind of distribution neither altitude nor basin area would have linear effects from zero to high values; they may present an almost linear effect inside a more restricted range. This implies that if the behavior of any predictor in not clearly known, the likelihood of presence predicted by the GLM should be used only for discriminatory purpose: the species is believed to be present when likelihood of presence is above 0.5 and absent with lower values.

Finally, the Geographic Information System (GIS) is a tool with increasing importance for environmental management. In this respect, all products of this work have the objective to contribute for an integrated environmental planning of the Jacuí River Hydrographic Basin. Moreover, the presumed distribution models can be useful to subsidize decisions related to the construction of new power dams. In this respect our data suggests that power dam planning, as potential barriers for fish migration, should consider the altitudinal threshold of 280-300 $\mathrm{m}$ as upstream limits of migratory fish in the Jacuí basin. Also, the proposed distribution models do not intend to substitute in loco sampling for verification of species occurrence. We intended, more than anything, to provide to the licensing agencies an independent tool to evaluate the environmental field data related to licensing of new dam.

\section{Acknowledgements}

The authors would like to thank the students of the Laboratório de Ecologia Aquática da PUCRS, especially Camilla Marques. Thanks also to CNPq for financial support (Universal 2006 - Process 471997-2006-4). 


\section{Literature Cited}

Agostinho, A. A., L. C. Gomes, S. Veríssimo \& E. K. Okada. 2004. Flood regime, dam regulation and fish in the upper Paraná River: effects on assemblage attributes, reproduction and recruitment. Reviews in Fish Biology and Fisheries, 14(1): 11-19.

Agostinho, A. A. \& H. F. Julio Jr. 1999. Peixes da bacia do alto rio Paraná. Pp. 374-400. In: Lowe-McConnell, R. H. (Ed). Estudos ecológicos de comunidades de peixes tropicais. São Paulo, Editora da Universidade de São Paulo, 534p.

Araújo, N. B. \& F. L. Tejerina-Garro. 2009. Influence of environmental variables and antropogenic perturbations on stream fish assemblages, Upper Paraná River, Central Brazil. Neotropical Ichthyology, 7(1): 31-38.

Azpelicueta, M. M., J. G. Lundberg \& M. Loureiro. 2008. Pimelodus pintado (Siluriformes: Pimelodidae), a new species of catfish from affluent rivers of Laguna Merín, Uruguay, South America. Proceedings of the Academy of Natural Sciences of Philadelphia, 157: 149-162.

Bistoni, M. A. \& A. C. Hued. 2002. Patterns of fish species richness in rivers of the central region of Argentina. Brazilian Journal of Biology, 62(4): 753-764.

Braun, A. S. 2005. Biologia reprodutiva e identificação do uso de lagoa marginal como sítio de reprodução para espécies dominantes da ictiofauna da Laguna dos Patos, RS. Unpublished Ph.D. Dissertation, Pontifícia Universidade Católica do Rio Grande do Sul, Porto Alegre, 145p.

Brito, J. C., E. G. Crespo \& O. S. Paulo. 1999. Modeling wildlife distributions: Logistic Multiple Regression vs. Overlap Analysis. Ecography, 22: 251-260.

Carolsfeld, J., B. Harvey, C. Ross \& A. Baer. 2004. Migratory fishes of South America: biology, fisheries and conservation status. Ottawa, World Fisheries Trust/World Bank/IDRC, 380p.

Garutti, V. 1988. Distribuição longitudinal da ictiofauna em um córrego da região noroeste do estado de São Paulo, bacia do rio Paraná. Revista Brasileira de Biologia, 48(4): 747-759.

Godoy, M. P. 1967. Dez anos de observações sobre periodicidade migratória de peixes do Rio Mogi Guassu. Revista Brasileira de Biologia, 27(1): 1-12.

Godoy, M. P. 1987. A escada de peixes de Cachoeira de Ema, rio Mogi Guassú, estado de São Paulo, Brasil. Comunicações do Museu de Ciências e Tecnologia da PUCRS, Série Zoologia, 43: 139-151.

Guisan, A., S. B. Weiss \& A. D. Weiss. 1999. GLM versus CCA spatial modeling of plant species distribution. Plant Ecology, 143(1): 107-122.

Hall, C. A. S., J. A. Stanford \& F. R. Hauer. 1992. The distribution and abundance of organisms as a consequence of energy balances along multiple environmental gradients. Oikos, 65(3): 377-390.

Hise, R. T., M. Gable, J. P. Kelly \& J. B. McDonald. 1983. Factors affecting the Performance of Individual Chain Store Units: An Empirical Analysis. Journal of Retailing, 59(2): 22-39.

Labgeo. 2006. Modelos Digitais de Elevação para cada estado brasileiro, obtidos a partir do SRTM (Shuttle Radar Topography Mission), em formato imagem Idrisi e arquivo vetorial Idrisi das unidades da federação (IBGE, 2001). Available from: http:/ /www.ecologia.ufrgs.br/labgeo/SRTM_ZIP_RAR.php. Accessed 30 March 2006.

Malabarba, L. R. 1989. Histórico sistemático e lista comentada das espécies de peixes de água doce do sistema da Laguna dos patos, Rio Grande do Sul, Brasil. Comunicações do Museu de Ciências e Tecnologia da PUCRS, Série Zoologia, 2(8): 107-179.
Matthews, W. J., D. J. Hough \& H. W. Robison. 1992. Similarities in fish distribution and water quality patterns in streams of Arkansas: congruence of multivariate analyses. Copeia, 1992(2): 296-305.

Matthews, W. J. \& J. T. Styron-Júnior. 1981. Tolerance of headwater vs. mainstream fishes for abrupt physicochemical changes. American Midland Naturalist, 105: 149-158.

Pearce, J. \& S. Ferrier. 2000a. An evaluation of alternative algorithms for fitting species distribution models using logistic regression. Ecological Modelling, 128: 127-147.

Pearce, J. \& S. Ferrier. 2000b. Evaluating the predictive performance of habitat models developed using logistic regression. Ecological Modelling, 133: 225-245.

Petrere-Júnior, M., A. A. Agostinho, E. K. Okada \& H. F. Julio-Jr. 2002. Review of the Fisheries in the Brazilian Portion of the Paraná/Pantanal Basin. Pp. 123-143. In: Cowx, I. G. (Ed.). Management and Ecology of Lake and Reservoir Fisheries. London, Wiley-Blackwell, 416p.

Petry, A. C. \& U. H. Schulz. 2006. Longitudinal changes and indicator species of the fish fauna in the subtropical Sinos River, Brazil. Journal of Fish Biology, 69(1): 272-290.

Pitcher, T. J. \& P. J. B. Hart. 1982. Fisheries Ecology. Dordrecht, Kluwer Academic Publishers, 408p.

Pouilly, M., S. Barrera \& C. Rosales. 2006. Changes of taxonomic and trophic structure of fish assemblages along an environmental gradient in the Upper Beni watershed (Bolivia). Journal of Fish Biology, 68(1): 137-156.

Reyes-Gavilán, F. G., R. Garrido, A. G. Nicieza, M. M. Toledo \& F. Branã. 1996. Fish community variation along physical gradients in short streams of northern Spain and the disruptive effect of dams. Hydrobiologia, 321(2): 155-163.

Silveira, G. L. \& J. C. Cruz. 2005. Seleção ambiental de barragens: análise de favorabilidades ambientais em escala de bacia hidrográfica. Santa Maria, Universidade Federal de Santa Maria, 390p.

Súarez, Y. R. \& M. Petrere-Júnior. 2007. Environmental factors predicting fish community structure in two neotropical rivers in Brazil. Neotropical Ichthyology, 5(1): 61-68.

Syartinilia, S. T. 2008. GIS based modeling of Javan Hawk-Eagle distribution using logistic and autologistic regression models. Biological Conservation, 141(3): 756-769.

Tabachnick, B. G. \& L. S. Fidell. 1996. Using Multivariate Statistics. Northridge, Harper Collins College Publishers, 880p.

Vázquez, J. B., A. Lopez-Robles, D. F. Sosa \& M. P. Saez. 1979. Águas. Pp. 139-211. In: Vázquez, J. B., R. A. Miatello \& M. E. Roque (Eds.). Geografia Física de la Província de Córdoba. Buenos Aires, Boldt, 368p.

Vazzoler, A. E. A. M., H. I. Suzuki, E. Marques \& M. A. P. Lizama. 1997. Primeira maturação gonadal, períodos e áreas de reprodução. Pp. 249-265. In: Vazzoler, A. E. A. M., A. A. Agostinho \& N. S. Hahn (Eds.). A planície de inundação do alto Paraná: aspectos físicos, biológicos e socioeconômicos. Maringá, Eduem, 460p.

Accepted October 2, 2009 Published December 18, 2009 